\title{
Traditional Fishing Methods and Tools of the Kaibarttas: A Case Study in the Nalbari District of Assam: India
}

\author{
Md. Chirajul Haque ${ }^{1}$ \\ ${ }^{I}$ Ph. D Research Scholar, Department of Cultural Studies, University of Science and Technology, Meghalaya
}

\begin{abstract}
Nalbari district including a large part of the Brahmaputra with its tributaries, such as, Nona, Pagaldia, Burahdia, Borolia etc. has a big wealth of fish fauna. In fact, the success of fisheries in a country depends on proper catch of its fish fauna. Fish catching is one of the oldest occupations of mankind and fish has been also one of the most important food items of the human beings from the primitive time. In India million of people of fishermen community including Kaibarttas have been depending on this occupation. Like other parts of India, fishing is a caste based occupation in Assam and is traditionally practised by the Kaibarttas. Fishing is their only main traditional occupation of livelihood. The Kaibarttas of Nalbari district have been using several kinds of traditional fishing methods and tools since the past. These fishing methods and tools have remained static in some places and have shown little improvement in other places. This fishing community is specified as scheduled caste for Assam by the constitution order 1950 (a) Part II: Assam. Assam is full of fishery resources. According to 2011 census, the total Kaibartta population in Nalbari district is 17539 . This paper will be a sincere effort to study and explore the present scenario of the traditional fishing methods and tools used by the Kaibarttas of the Nalbari district of Assam. This paper will also attempt to describe the origin of the Kaibarttas.
\end{abstract}

Keywords: Nalbari District, Fishing Tool, Kaibartta, Scheduled Caste

\section{INTRODUCTION}

Fish catching is one of the oldest occupations of mankind and fish has been also one of the most important food items of the human beings from the primitive time. In fact, the success of fisheries in a country depends on proper catch of its fish fauna. In India million of people of fishermen community including Kaibarttas have been depending on this occupation. Like other parts of India, fishing is a caste based occupation in Assam and is traditionally practised by the Kaibarttas. The Kaibarttas, a constituent of fishing community, is an important caste of India. Fishing is their only main traditional occupation of livelihood. This fishing community is specified as scheduled caste for Assam by the constitution order 1950 (a) Part II: Assam. Assam is full of fishery resources. The Kaibarttas of Nalbari district of Assam has been surviving on their traditional knowledge based techniques for fish harvesting. According to 2011 census, the total Kaibartta population in Nalbari district is 17539. In India caste based society is a matter of controversy. The sixth schedule of the Indian constitution has declared the scheduled caste community as the weaker fragment of Indian caste based society. The Indian government has taken some large scale measures for the social, economic cultural and educational development of the people of this community. The people of this community have been declared socioeconomically backward by a public notification under Article 341[I] of the Indian constitution. As the Kaibarttas are one of the sixteen scheduled caste communities of Assam, so they are not exception to this problem as a whole. This paper will be a sincere effort to study and explore the present scenario of the fishing methods and tools used by the Kaibarttas of the Nalbari district of Assam. To study the origin of the Kaibarttas will be another attempt of this paper.

II.

AIMS AND OBJECTIVES

The proposed study aims at fulfilling the following objectives:

I. To describe the origin of the Kaibarttas.

II. To discuss the traditional fishing methods and tools of the Kaibarttas of this area.

\section{METHODOLOGY}

The methods adopted for writing this paper are that of multi-disciplinary approaches involving the socio-economic, traditional and religious dimensions. Collection of materials, field survey, case study, interviews and questionnaires are some of the techniques involved in writing this paper. Evaluation and analysis may also be implied as convenient tool of this study. Schedules and questionnaires will be made to collect data from the informants. The information collected will be checked and cross checked from various sources. Methods adopted for investigation of the proposed study are: I. Interview method. II. Case study method. The 
relevant data are collected from primary and secondary sources. The interview method is done on the following basis. The primary data are collected from the field survey. The secondary data are collected from books, journals, research papers, online sources, various census reports and government documents.

I. Social aspects: Tradition bearer and older persons of the area

II. Occupational aspects: Kaibartta fisher folk of the area.

\section{CASE STUDY AND THE DISCUSSION}

The Kaibartta, a constituent of fishing community is an important caste of India. They have been engaging themselves traditionally in the fishing trade which is supposed to be their main livelihood. The existence of the Kaibarttas is evident from the ages of the great epics, such as, the Ramayana and the Mahabharata. Major fishermen communities of India are generally found in Tamilnadu, Maharastra, Kerala, Gujrat, Karnataka, Andhra Pradesh, Assam, West Bengal, Orissa, Bihar and Uttar Pradesh. Fish catching is one of the oldest occupations of mankind. In India million of people of fishermen community including Kaibarttas have been depending on this occupation. Like other parts of India, fishing is a caste based occupation in Assam and is traditionally practiced by Kaibarttas. The kaibarttas of Nalbari district of Assam have been surviving on their knowledge based techniques for fish harvesting. Their economic condition of the Kaibarttas is not sound. They have been connecting with the same main age-gold occupation of livelihood, i.e. catching fishes is their traditional occupation of livelihood. In due course of time, the Domes or Nodiyals of Assam are known as Kaibarttas. Kaibartta and Namasudra are the two major scheduled castes in Assam sharing more than half of the total Population. It is very difficult to decide when the Kaibarttas came to Assam. According to some sources the Kaibarttas came to Assam in the pre-historic time. It is assumed that the Kaibarttas started to live permanently in Assam approximately from the $4^{\text {th }}$ century. When we go through several religious books, Puranas and historical documents it can be said that the Kaibarttas migrated mostly from Orissa and Gour Pradesh. During the reign of Ahoms, many Kaibarttas come to Assam to avoid the wars, taxes and Political ups and downs. To catch fishes in the Puthimari, Kalajal and Baralimari beels, two Kaibarttas were brought to Assam. Later on these two Kaibarttas brought many Kaibarttas and settled themselves on the soil of Assam. During the invasion of Maan and the reign of English many Kaibarttas migrated to Assam as they felt insecure. After the independence many Kaibarttas came to Assam from West Bengal. Some scholars, on the other hand, opine that the Kaibarttas are the primitive people of Brahmaputra valley or Assam valley. The old books and the wall writing also support the opinions of these scholars. Hajor Barman, the king of old Kamrupa also included the names of Kaibarttas in the stone writing. In the same way, the stone and wall writing of the Middle Age also proves the existence of some Kaibartta villages. ${ }^{1}$ The Kaibarttas were the makers of civilization in the Indus valley at Harrapa and Mahenjodaro. They were the developers of Indian writing, township and drainage and central heating system before 2500 B.C. The Kaibarttas were of royal caste. Historian, such as, Gangabandhu Singh has referred to the Padma Purana and Brahma Vaibarta Purana and come to the conclusion that 'Mahisyas' and 'Kaibarttas' are the same castes.The 'Kaibartta' is Sanskrit word which means one who depends on water. In other words, Kaibartta is a community that earns its livelihood from the related occupation. According to anthropology the Kaibarttas belong to the Drividian origin. 'Kalika Purana' a historical documents explains that the Kaibarttas were living in Kamrup even before the $17^{\text {th }}$ century. According to the Bengali historian, Sevenanda Bharati the ancient home of Mahishya race or Kaibarttas is near the present day Ratnavati on the bank of Narmada. This was known as Mahishamati. ${ }^{2}$ During the Brahmin and Shanhita Ages the Kaibartta was known as Kimvarta where 'kim' means ugly and 'varta' means occupation. According to Adhunik Asomiya Shabda Kosh, Kaibartta means a caste the people of which run their lives by catching fishes. According to 'Saral Bangla Abhidhan' Kaibartta means those who live near water and run their lives depending upon it. ${ }^{3}$ According to the scholar, Nripendra Kumar Dutta 'Kaibartta' and 'Kebarta' have come from the root words 'Kebartta' and 'Keot' which are Sanskrit. These two words originally represent Nisad and Pukkash.Generally a society is consisted of the people. Society includes the political issues, economic issues, friendship, mutual understanding, relationship etc. It is also the combination of Arts, religion and language. It is a web of social relationship. Several organisations help in establishing social relationship. Social relations are complex. These institutions, associations and groups control and regulate the mutual relationship between individuals. Rightly observes R.N. Sarma: "Society is an organisation, a system or pattern of relationship among human beings. It may be defined as the total complex of human relationship, a complex of forms or process, living and growing by interaction." 4

The Kaibarttas generally live interspersed with the general caste people in Assam. It is observed that the Kaiabrtta group of people in Nalbari district also live along with the general caste people in the same village. But they have kept own identity by practising their own cultures. But the Kaibarttas are not seen living together in a separate village. But they are seen living in a Suba i.e area inside a village. The Kaibartta families are patriarchal in nature. The whole family affairs centre round the father as he is the head of the family. According to the social customs of the Kaibarttas, when the head of the family dies, his sons cremate his dead body. They also observe the Sraddha ceremony. After the death of father, the son automatically inherits the property. On the 
other hand if the man dead has no male issue, daughter inherits the whole property. In the social system of the Kaibarttas they are categorised into four classes: 1. Halwa Dom. 2. Jalwa or Jaliya Dom. 3. Suriya Dom.4. Kacharipuria Dom. The main occupation of the Halwa Doms is the cultivation. They tilt the soil with plough. But they also catch fishes and sell it in the market. Socially, Halwa Doms are more respected than the Jalwa Doms. The Jalwa or Jaliya Doms basically run their life by catching fishes. They are also known as the following ways: 1. Patni. 2. Dom-Patni. 3. Dom or Nodiyal. 4. Motak Dom. Motak Doms are different from Nodiyals in some respects. The Nodiyals follow the Vaisnavism. Motak Doms are the pupils of Moamoria Goseion. ' Motak Doms do not eat 'Sal fish'. On the other hand the Nodiyals do not even touch the 'Sal fish'. Social status of Jaliya Doms is higher than the Sauriya Doms. The Souriya Doms carry the dead body and they rear pig as occupation. The Kacharipuria Doms also carry the dead body and play the role of sweepers. Other Doms hate them for their occupation. ${ }^{6}$

\subsection{Study Area}

Nalbari district is situated in between $26^{\circ} \mathrm{N}$ and $26.51^{\circ} \mathrm{N}$ latitudes and $91^{\circ} \mathrm{E}$ and $91.47^{0} \mathrm{E}$ longitudes. Nalbari district is large in areas as well as in population concerned. Besides, this area have sufficient no of fishery resources, such as ,the Brahmaputra river and its tributaries.The Kaibarttas of this area have been surviving on their traditional knowledge based techniques for fish harvesting. Therefore, this area is found to be suitable for the study.Nalbari district occupies diversified water bodies in various forms, such as, beel-Behkuri, Dhansiri, Bouta etc, swamp, wasteland, ponds and tanks. The Kaibarttas of Nalbari district have been adopting the old traditional techniques of fishing as these techniques of fish harvesting have been generously passed on to newer generations by the older ones. Bhutan falls in the north of Nalbari district and Kamrup district is on the east of Nalbari district. The Brahmaputra falls on the south of Nalbari district and Barpeta district is on the west of Nalbari district.

\subsection{Demography}

Nalbari district is covering an area 2257sqkm.According to 2011 census, the total population Nalbari district is 769919. Among which the number of male is 395804 and the number of female is 374115 . Kaibartta is a major scheduled caste in Assam sharing more than half of the total population. According to 2011 census, the total Kaibartta population in Nalbari district is 17539 among which the number of male is 8845 and the number of female is 8694 .The 2011 census also reveals that 85 percent of the scheduled caste population lives in rural areas. Wide variation is seen regarding the rural urban distribution of the scheduled caste population of Assam. Namasudra records highest 35.52 percent of total scheduled caste population while Lalbegi records the lowest of 0.04 percent of total scheduled caste population. On the otherhand Hira, Muchi and Kaibartta are Predominant in rural areas having more than 85 percent of rural population.

Table-1: Distribution of Scheduled Caste Population in Nalbari District ${ }^{1}$

\begin{tabular}{|lll|}
\hline Sl.no. & Name of sc & Sc persons \\
\hline $\mathbf{1}$ & Bansphor & 106 \\
\hline $\mathbf{2}$ & Bhuinmali & 2529 \\
\hline $\mathbf{3}$ & Brittial Bania & 3049 \\
\hline $\mathbf{4}$ & Dhupi & 4091 \\
\hline $\mathbf{5}$ & Dugla & 15 \\
\hline $\mathbf{6}$ & Hira & 1625 \\
\hline $\mathbf{7}$ & Jalkeot & 1490 \\
\hline $\mathbf{8}$ & Kaibartta & 17539 \\
\hline $\mathbf{9}$ & Lalbegi & 2 \\
\hline $\mathbf{1 0}$ & Jhalo & 862 \\
\hline $\mathbf{1 1}$ & Mahara & NIL \\
\hline $\mathbf{1 2}$ & Mehtar & 146 \\
\hline $\mathbf{1 3}$ & Muchi & 372 \\
\hline $\mathbf{1 4}$ & Namasudra & 17687 \\
\hline $\mathbf{1 5}$ & Patni & 31 \\
\hline $\mathbf{1 6}$ & Sutradhar & 244 \\
\hline
\end{tabular}

${ }^{1}$ Source: Census of India, 2011 
Besides scheduled caste, the scheduled tribe population of Assam is 3308570. Among scheduled tribes Bodos represent nearly half of the scheduled tribe population of Assam. There are eight notified scheduled tribes in Assam, such as, Bodo, Miri, Rabha, Kachari, Lalung, Dimasa, and Deori.

The scheduled caste and the scheduled tribe belong to Hindu religion. Thus Assam is constituted of several religious communities, such as, Hindu, Anukul Thakur, Baishnava, Bathau, Kabir Patni, Sanatan Dharma, Muslim, Christian, Sikh Buddhist and Jain.

\subsection{Occupational Structure}

Table-2: Statistics of Fisheries on Inland Water Bodies in Assam²

List of un-registered beels in Nalbari district

\begin{tabular}{|lll|}
\hline S1. No. & Name of beel & Water in Hect. \\
\hline 1. & Lanthani beel & 20.00 \\
\hline 2. & Kashkhuuna beel & 10.00 \\
\hline 3. & Kakan Kuchi & 10.00 \\
\hline 4. & Banni bani & 15.00 \\
\hline 5. & Mugdi & 10.00 \\
\hline 6. & Baiha beeel & 25.00 \\
\hline 7. & Ghilajari beel & 50.00 \\
\hline 8. & Lakhupur beel & 30.00 \\
\hline 9. & Boripith Borali beel & 15.00 \\
\hline 10. & Maguri beel & 7.00 \\
\hline 11. & Malakduwa & 50.00 \\
\hline 12. & Jalkata & 35.00 \\
\hline 13. & Bhagia beeel & 15.00 \\
\hline 14. & Hablakhowa & 75.00 \\
\hline
\end{tabular}

${ }^{2}$ Source: Department of Fisheries, Government of Assam

The occupation related to the Kaibarttas, can be classified into three categories, such as, primary, secondary and tertiary. The Primary occupations are agriculture, animal husbandry, fishery, poultry forming, lumbering etc. The Secondary occupations include people engaged in mining and querying, manufacturing and construction. The Kaibarttas, mainly associated with the occupation fishing and its trade. Of course, now-a-days the young generation of the Kaibarttas have changed their traditional occupation of fishing. To run their life smoothly, they have chosen the occupation of wage earning, rickshaw pulling, hand cart pulling etc. A poor number of people are holding their govt. service.

\subsection{Traditional Fishing Methods}

India, with its long sea-cost and extensive riverine and estuarine waters, has a big wealth of fish fauna. In fact, the success of fisheries in a country depends on proper catch of its fish fauna. In India a large variety of crafts are designed for marine and inland fishing. The nets or gears and other devices for catching fishes are also numerous and ingenious. Both crafts and gears were invented centuries ago and probably have remained static and have shown little or no change or improvement in India. Actually the capture of fishes is as important as pisci-culture methodsUnlike the modern fishing techniques, the Kaibartta people of this area have been using the indigenous methods of fish harvesting. The methods of fish catching among the people of this community have been passing on traditionally from one generation to other generation. Bamboo has been playing an important role in making the fishing implements in rural areas. Bamboo and cane have been playing an important role in forming the Assamese culture. Some of the fishing implements are as bellow. Some fishing tools used in Assam are adil, cup, galfula, choklat, chuki, cheka, khewali jal, ghokot jal, tangna jal, langi jal, zilikini, khuha, pauri, pabang, shalha, hukma. ${ }^{7}$

Some of the methods of fish harvesting among the Kaibarttas of Nalbari district are as follows. ${ }^{3}$

\section{Source: Field Survey}

\subsubsection{Chali Di Mas Dhara}

'Chali di as dhara' i.e. catching fish with attractants is one of the old traditional methods of fish catching among the Kaibarttas of this area. This method is generally adopted to catch fishes before harvesting the crops when the water level becomes low in the paddy field. It is used in the midst of crops. They use this method in the evening or morning of the day. This method can be categorised into four divisions. These are as follows.

4.4.1.1Bokar chali

4.4.1.2 Malor chali 


\subsubsection{Sungar chali}

\subsubsection{Bandhar or Latir chali}

\subsubsection{Bokar Chali}

It is a traditional method of catching fishes among the Kaibarttas of this area. This method is generally adopted in the low level water in the midst of paddy field. The quantity of fishing becomes greater if the paddy fields concerned are connected with the stream. The Kaibartta fisher folk can easily prepare the 'Bokar chali'. The ingredients necessary for this chali are available among them. The three ingredients for the preparation of this chali are the rice bran, cow-dung and mud. The rice bran, cow-dung and mud are mixed well and then tight dough is prepared. It is prepared nearby the targeted areas. The fisher folk generally bring the cow-dung and rice bran with him from home. After the preparation, the chali i.e. attractant is kept in the targeted areas. As a sign, a small bamboo stick is kept erected in the targeted place where the dough is kept. The bamboo stick helps the fisher folk in finding out the targeted place easily. The fishing equipments used in such fishing activities are the Zulki i.e. a kind of cast trap made of bamboo splits. It is approximately 2 feet in length. The lower portion of the Zulki is wide open and its upper portion is like a narrow hole. Generally small fishes are caught by such fishing activities. Zulki is used to catch the small fishes and the Pola is used to catch the big fishes. The attractants are kept before one or two hours of catching the fishes.

\subsubsection{Malor Chali}

Malor chali is also popular among the Kaibarttas of this area. It is also a kind of traditional method. The most important element for this method is the rice bran. The dry rice bran is used in this method as an attractant.

Another important element for this method is the peel of banana tree. The peel of banana tree is locally known as 'Kal Dona'. The Kal Dona is kept on the surface of the water. Then some bamboo sticks are erected inside and outside the square. The bamboo sticks are used so that the wind and flow of the water cannot move away the Kal dona. Thus the Kol Donar chali is prepared. Then the rice chaff is kept inside the square that floats on the water. The Kal Dona is used so that the rice bran cannot spread throughout the water body. Then after one hour the actual activity of catching fishes is started. Asra Jal is basically used to harvest the fishes.

\subsubsection{Sungar Chali}

Sungar chali is another traditional method of catching fishes among the Kaibarttas of this area. In this method, basically the rice bran and the boiled rice are the main attractants. For the preparation of this method a bamboo is cut into several short parts keeping one side of each part closed. The rice bran and boiled rice are kept inside the short bamboo pieces. Then these filled up bamboo pieces are kept in the ponds or tanks for one or two days.

\subsubsection{Latir Chali}

In this method the 'Lati' i.e. a small dam is itself an attractant. The Lati is made of mud in the midst of the paddy field. This method is used during the winter season when the water level is low in the field. The big fishes are caught along with the small fishes by implementing this method. The Lati is kept for many weeks.

\subsubsection{Fishing in Dal}

Community fishing i.e. fishing in 'Dal' is popular among the Kaibarttas of this area. The community fishing is executed in a group or band. This community fishing is done by implementing various traditional methods. These methods are adopted to catch fishes in the open fields or beels, ponds and lakes.

These methods are categorised as follows.

4.4.2.1 Ber di mas mara

4.4.2.2 Dal bandhi mas mara

4.4.2.3 Zora kata

4.4.2.4 Bana di mas mara

\subsubsection{Ber Di Mas Mara}

Ber di mas mara is an old traditional fishing method. The fishing equipments used in this method are the 'Zakhe' and 'Khaloi'. Zakhe is a kind of cast trape with the help of which fishes are caught. The fishes caught are kept in the Khaloi. Both the male and female fishers catch fishes by this method. Each of the fisher folk uses a Zakhe and a Khaloi to catch fishes. This method is adopted both in the morning and afternoon. At the very beginning the fisher folk select an area. Then they close the whole area by erecting a small dame with the help of aquatic weeds and grass. Before erecting the dam they keep a narrow way. When they make noise by clapping, disturb the water by hands and feet, the fishes entered coverd area through the narrow way. Then 
instantly the narrow way is closed and the fishes are trapped inside the closed area. The fisher folk then catch the fishes with help of Zakhe.

\subsubsection{Dal Bandhi Mas Mara}

The Kaibarttas of this area observe the traditional community fishing during the Magh domahi. The whole Kaibartta community take part in such fishing. Such fishing generally practised in the community pond or stream. All the old and young catch fishes in such fishing. The fishing implements used are the Zakhe, Khaloi, indigenous gear, small net etc. The water is disturbed by the participation of a huge crowd. The fishes are frightened and come out from its shelter. The fishes get confused and fail to escape towards a safer place. Thus the fishes are caught.

\subsubsection{Zora Kata}

Zora kata i.e. light fishing is a traditional fishing popular among the Kaibarttas. The fishing equipments used in such fishing are Ballam i.e. gear, Kochtar i.e. gear, Dagar i.e. knife and Kaachi i.e. scissors. This method is practised in the paddy field during the rainy season. Fishes are generally come out from shelter to clear water in search of food and oxygen. Then the fisher folk wound the fishes with fishing equipments and catch the fishes. Fishes are caught at night by using this method.

\subsubsection{Bana Di Mas Mara}

Bana dim as mara is an old traditional fishing method. This method is popular among the Kaibarttas. Bana is made of bamboo strips with the help of coir and jute. At the very beginning, the bamboo strips are prepared. Then these strips are knitted with the help of coir and jute. These are placed in the way through which the fishes migrate. It is fixed with the help of some bamboo sticks and rope. The banas are placed keeping a way to enter the fishes with the flow of water into the collection area. The interesting thing is that the fishes only enter into the collection area, but it cannot come out from the trap. The collection area is locally called as 'ghera'

This method is a long time method. It continues for many days. After collecting the fishes, the fisher folk have to catch the fishes with the help of other fishing equipments. In such method, the fishes are remained alive.

\subsubsection{Pola Mara}

Pola is a kind of fishing implements made of bamboo. The male folk use this implement. It is used to fish in the small streams. In such kind of fishing generally a group of people participate. But sometimes only one person may catch fish using this implement.

\subsubsection{Zakhare Mas Dhara}

Zakha is another kind of fishing implement. This equipment is generally used by the women folk. Zakha fishing is done in group in beeel or small stream. Sometimes the Zakhas are kept in a line and the women come from the opposite side shaking the water so that the fish moves towards the 'Zakha'. The fishermen catch fishes using this method in April and May.

\subsubsection{Bana Diya}

Banas are made of bamboo splints using cane or string. It is like a fence where the bamboo splints are connected by the cane or string. This is kept sloppily against the current of the water. Some bamboo pieces support the Bana which are fixed in the water. The back side of the Bana is covered with a net. The fishes jump when obstructed by the Bana and take shelter in the net.

\subsubsection{Chepa Pata}

Chepa is a kind of traditional fishing equipment. It is made of some small bamboo sticks. One side of it is closed. The other side has a small passage. This is used in swallow water. This tool is used through the whole year. Small fishes like kawai, gorai, puthi, turi, biota, sang are caught by this tool.

\subsubsection{Pari Pata}

Pari is made of bamboo. It is long and its passage is wide. Its length ranges from 3 feet -4.5 feet. One side of it is narrowand closed. The other side is quite open and some bamboo sticks are interwoven on this side. It is kept in water for few days and then checked. This tool is used during the rainy season for big catch of fishes. During the survey it is come to know the use of this tool is less than the others because of the scarcity of fishes.

\subsubsection{Dalnga Pata}

Dalnga is a kind of fishing trap. Its shape is like a triangle. It is made of bamboo splints. This equipment is kept in the water. This is filled with upper part of bamboo and wastage of rice to attract the fishes. After two or three days it is checked and brought to bank of stream or beel with the help of three people. 


\subsubsection{Chohra Pata}

Chohra is a kind of fishing implement made of bamboo splints. This kind of fishing trap is used in the swallow water the rainy season. Some small and low dams are erected in the paddy fields for planting crops. Chohras are kept in a row in these damps. The back side of it is narrow and closed and front part is wide.

\subsubsection{Dingara Pata}

Dingara is large kind of fishing trap. It is made of bamboo. It is used in the stream to catch big fishes. This tool is mainly used during the rainy season when the water level becomes high. It is also fixed in the midst of paddy fields raising a small dam. The fisher folk can consume the fishes and sell it in the market.

\subsubsection{Masor Uzan Utha}

During rainy season the fishes like Kawai, Singi, Magur etc. come out from the ponds, streams etc. That kind of activity of fish is known as Masor Uzan Utha. People catch the fishes with the help of Pal, Zulki, Zal, Zakhe.

\subsubsection{Khal Shisa}

Khal Sisa is a traditional fishing technique of the Assamese people. Khal is a small kind of pond. Some small ponds are dug out near the beel, stream and river. These ponds are filled with root of the trees, the upper part of the bamboo etc. during rainy season. The fishes take shelter in such ponds. When the water level becomes low, the open mouth of the ponds is closed. Thus the fishes are caught.

\subsubsection{Zora Kata}

Zora Kata is an old fishing activity. In this activity 'Zora' or 'Veta' i.e. source of light is used. This fishing activity is practised at night in the rainy season. The 'Veta' is kept in one hand and a knife or fishing gear is kept in the other hand. The fishes are seen in the swallow water with the help of the light.

\subsubsection{Barasi Pata}

Barasi pata is a kind fishing activity in the rural areas of Assam. Bamboo stick, hook and a string are necessary elements for this activity. This are of several types: Khuti Barasi, Chip Barasi, Punga Barasi Dan Barosi, Dhan Borosi etc. The attractants, such as, frog, small fish, insects are attached in the hook.

\subsubsection{Safa Mara}

Safa fishing is an old traditional fishing. For this fishing method sack of rice is necessary. The sacks of rice are stitched by the local fisher folk by hand. It is called 'safa'. Then all the four sides of the 'safa' are connected by a piece of long string. Then the fishing area is covered with the help of bana. The safa is kept inside it and three long piece of bamboo sticks are put under the safa. The fishes under the safa are in trouble because they cannot take air properly and make their way by the side of the bamboo pieces. The fishes come out under the safa and gather over it. Thus the bamboo sticks are checked for three times. The safa is kept in the evening and checked in the next morning.

\subsubsection{Chera Mara}

Chera mara is the last fishing in the year. The mahaldars i.e. owner of the beel catches fishes for the last time in the year in March and April. After $18^{\text {th }}$ Chot i.e. an Assamese month the local people can catch fishes without paying any tax to the mahaldars. After this fishing new agreement is made with the government.

\subsubsection{Ghera Mara}

Ghera mara is an old traditional fishing method. This method is popular among the Kaibarttas.

Bana is made of bamboo strips with the help of coir and jute. Bana used in this method is known as 'Sar bana' and 'Ghera bana'. At the very beginning, the bamboo strips are prepared. Then these strips are knitted with the help of coir and jute. These are placed in the way through which the fishes migrate. It is fixed with the help of some bamboo sticks and rope. The banas are placed keeping a way to enter the fishes with the flow of water into the collection area. The interesting thing is that the fishes only enter into the collection area, but it cannot come out from the trap. The collection area is locally called as 'ghera'

This method is a long time method. It continues for many days. After collecting the fishes, the fisher folk have to catch the fishes with the help of other fishing equipments. In such method, the fishes are remained alive.

\subsubsection{Pouta Mara}


Pouta mara is an old traditional fishing method practised by the Kaibarttas of this area. For this fishing method boat and peel of the banana tree are the two main necessary things. At least two men are necessary for this method. Two bamboo sticks are attached in the both ends of the boat across the water level. Then the peel of the banana tree is fixed on the bamboo sticks. The two fisher folk sit on the both ends of the boat and slowly sail the boat. The small fishes on the surface of the water are hit by the banana peel and jump over it. The jumping fishes fall in the boat. Thus the fishing is accomplished.

\subsubsection{Sai Mara}

Sai mara is an old traditional fishing method. It is also known as Jeng Mara or Katal Mara. According to Y. S. Yadav Katal Mara is extensively used in the beel fisheries of Assam. Sai or katal is a lure. It is made of accumulated mass of bushes, weeds, tree branches, upper part of a bamboo and root of the trees etc. These are kept in water at the selected areas for $2-5$ months. The fishes take shelter there and make their abode. During fishing the entire area is enclosed with the help of banas and if possible dame is erected. Then the lures are kept aside and fishing starts inside the boundary. ${ }^{8}$

\subsection{Fishing Tools and Bamboo and Iron}

The Kaibarttas, a fishing community make several items of fishing tools for catching fishes. These tools help in forming the economy of the Kaibarttas. Among various fishing equipments the following are frequently used.

\subsubsection{Chepa}

Chepa is a kind of drum like fishing equipment. It is made of bamboo sticks. The two ends of it are flattened and closed. It has an inlet at the middle.

\subsubsection{Julki}

Julki is a kind of fishing equipment. It is also made of bamboo and used to fish at shallow water. Julki has resemblance with Palah in shape. But Julki is smaller than Palah. Its holes are smaller than Palah. Small fishes are caught with help of the Zulki by using different kinds of chali i.e. attractants.

\subsubsection{Zakhe}

Zakhe is a kind of fishing tool. The Zakhe is generally used by the womenfolk. It is a kind of triangular basket. One end of Zakhe is opened and the three triangular sides are closed at a point at the other end. The three sides are attached to a bamboo handle which is three or four feet in length.

\subsubsection{Palah}

Palah is made of bamboo split. The bamboo splits are fastened together by cane strips. It is $4.5 \mathrm{~m}$. in height and $3 \mathrm{c} . \mathrm{m}$. in diameter at the base.

\subsubsection{Bana}

Bana is another kind of equipment for fishing. It is a kind of fencing and made of bamboo. Bana is generally used after the flood season. After flood when the water level in the river Brahmaputra is reached and the water flows from the beels towards the deep areas, the fishermen enclose at the different suitable low-lying places with their bana. It is done to prevent the in-coming fishes from escaping back into the rivers. Some divisions of Bana are Shar, Ghera Bana, Ghera Chepa Bana etc. The Bana may be of different length. These are mainly from 3 feet to 5.5 feet

\subsubsection{Loiha}

Loiha is a kind of fishing tool. It is used in carrying fishes from one place to another place. The front part of it is wide enough. The other side of it is closed and has a bend. The front part and back part are connected by cane or piece of string.

\subsubsection{Gheni}

Gheni is a cylindrical fishing trap. Its bottom is slightly flat. It has also a door at the top of the tool. One end of it is concave and has a narrow orifice. The large fishes are caught with the help of this trap. It is kept in the beel and checked after 4-7 hours.

\subsubsection{Deli or Gas}


Deli is also locally known as Gas. It is also a traditional fishing related tool. The fishes caught are kept in this tool. This tool is kept in the water and fixed it with the help of a bamboo stick. The fishes are kept here to make the fishes alive.

\subsubsection{Pachi}

Pachi is bamboo basket where fishes are kept for selling. It diametrically ranges from $70 \mathrm{~cm}$. $-100 \mathrm{~cm}$. Its depth ranges from 1 feet -2.5 feet.

\subsubsection{Goildha}

It is a rectangular shaped fishing trap. It has a long opening where the bamboo splits are interwoven with the help of the cane. The fish can only enter through this entrance but cannot come out. The other side has a small door through which fishes are brought out.

\subsubsection{Torowal}

Torowal has been using by the fisher folk since long past as wounding tool for catching fishes. It is used by the Kaibarttas also. This kind of tool is used at night in executing the Zora Kata fishing method. Zora Kata is executed at night by at least two people and sometimes more than two. The main tool in such method is the Torowal made of iron. The fishes are wounded with the Torowal and caught by grappling in the mud.

\subsubsection{Kochtar}

Kochtar is a kind of impaling tool made of umbrella sticks. The number of such sticks ranges from 9-13. One end of it is very sharp. It is used to catch fishes by piercing. It is used at night for fishing. Sometimes a group of people go for fishing at night with the help of boat. In such activity Veta i.e. a kind of traditional light is used.

\subsubsection{Koinal}

Koinal is also a kind of impaling tool for fishing. The number of iron sticks of which one side are sharp enough ranges from $7-9$. These iron spears are attached with a small bamboo pole.

\subsection{Fishing Net}

There are several kinds of fishing nets are used for fishing activity besides the fishing implements made of bamboo. Some of the fishing nets are as bellow. The jal i.e. net is a kind fishing implement which is made of nylon strings. In Assam several kinds of fishing net are found using among the fishing communities. These are Theki Jal, Kami Jal, Sangla Jal, Bheli Jal etc. ${ }^{51}$ Theki Jalis kept in the water and checked like paddle grinder. So it is called Theki Jal. It is used in the stream, beel and pond. In making Kami Jal a pair of long bamboo splints is used. So it is called Kami Jal. This kind of net is generally used in the Brahmaputra. Sangla jal is like the Kami Jal. But its length is less than the Kami Jal. This kind of net is used in the deep water. Bheli Jal is another kind of fishing net used by the Assamese people. The fisher folk use this net in the Brahmaputra. Besides, there are found several kinds of fishing net using among the Kaibarttas of Nalbari district 51. Source:

\subsubsection{Asra Jal}

Its upper side is closed and lower part is wide enough. The lower part is attached with some iron balls making some pockets. A long piece of string is also attached with the upper part of the net.

\subsubsection{Langi Jal}

Langi Jal is another kind of net. It is kept in the water in the evening and checked in the next morning. These are rectangular shaped fishing net. Two ropes are connected at the head and foot of the net. The head rope is attached by floats at the fixed intervals and the foot rope is also attached by sinkers at fixed intervals. These nets are set in the beel vertically in line and in cyclic manner. Sometimes these nets are dragged from one place to another place. The fisher folk disturb the fishes by beating the tin drum or hitting the water by bamboo pole. As a result fishes moves in frustration and get entangled in the net. It is of many types, such as, Puthi Langi, Kowai Langi, Gorai Lnagi, Ari Langi etc.

\subsubsection{Fasi Jal}

Fasi Jal is also used in Brahmaputra. This kind of net has big holes. This kind of net is used to catch Elish fish. It has similarity to that of the Langi jal. It is gill net. But, unlike the Langi Jal the foot rope is devoid of sinkers. These are made of cotton and nylon. The operation method is same as that of the Langi Jal. It is of several types, such as, Roufasi Jal, Ari Fasi Jal, Karal fasi Jal etc. 


\subsubsection{Parngi Jal}

It is also a kind of tradition fishing net. All the four sides of it are connected with a piece of long rope. The four corners of the net are prepared by keeping a hole with the help of this rope. It is then fixed on four pieces of bamboo sticks known as 'Toni'. These sticks are also fixed with the help of two bamboo pieces. It is locally known as 'Thorka'. The Thorka is then fixed by a bamboo pole and a long rope. At the time of checking the net is dragged towards the body of the fisher folk with the help of the rope.

\subsubsection{Pah Jal}

It is a kind of scooping tool for fishing. The fishing method related to Pah Jal is known as scooping. In such method the Pah Jal is first submerged and then it is pulled rapidly out of the water. It is supported on a round or rectangular bamboo frame. The mesh size of this net is about $65.0 \mathrm{~mm}$. During operation a man standing on the one end of the boat drifts the net. This operation is specially done for the hilsa fish.

\subsubsection{Dheki Jal}

The shape and structure is same as that of the Parngi Jal. The only exception is that it is checked with the help of the feet like a paddle grinder. So it is called Dheki Jal.The size is also bigger than the Parngi Jal. It is used for catching big amount of fishes in the stream, river or beel.

\subsubsection{Mushari Jal}

Mushari Jal is a kind of surrounding net. It is locally known as Mohri Jal. It is made of $2-5$ pieces of rectangular nets of nylon. Each of the pieces ranges from $25-30 \mathrm{~mm}$. in length and $7-10 \mathrm{~mm}$. in breadth. The lower margin and the upper margin of the net are connected by two jute ropes known respectively as head rope and foot rope. The foot rope and head rope of some nets are attached by floats and sinkers respectively and some are remained free. For the operation of such net $5-7$ men are necessary.

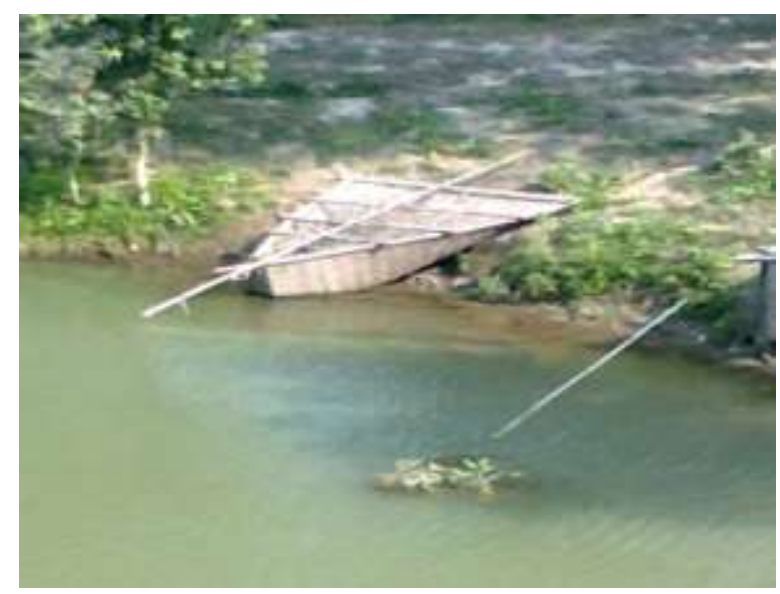

Fig. 1: Dalnga

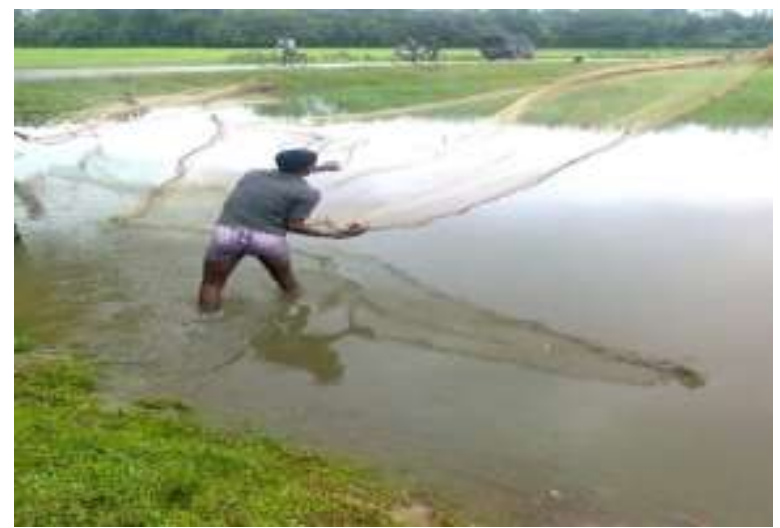

Fig. 2: Asra Jal 


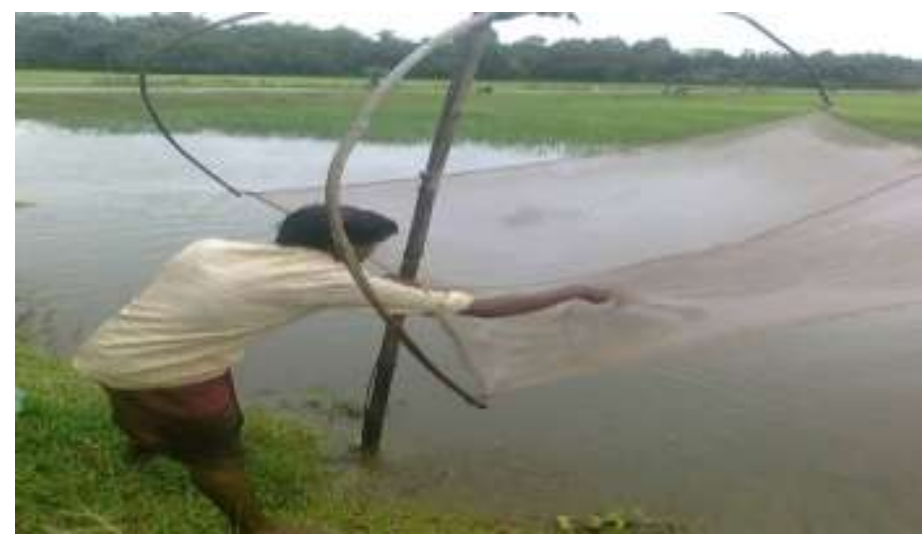

Fig. 3: Parngi Jal

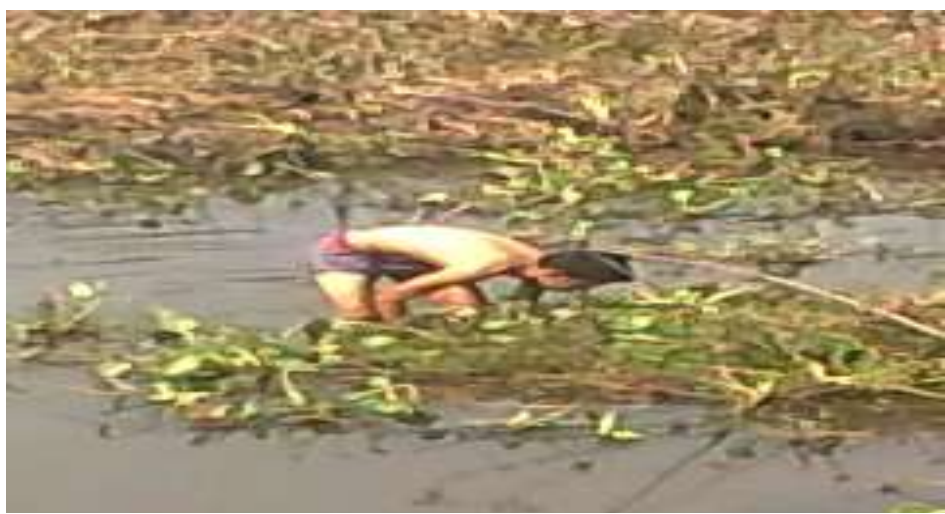

Fig. 4: Hand Fishing

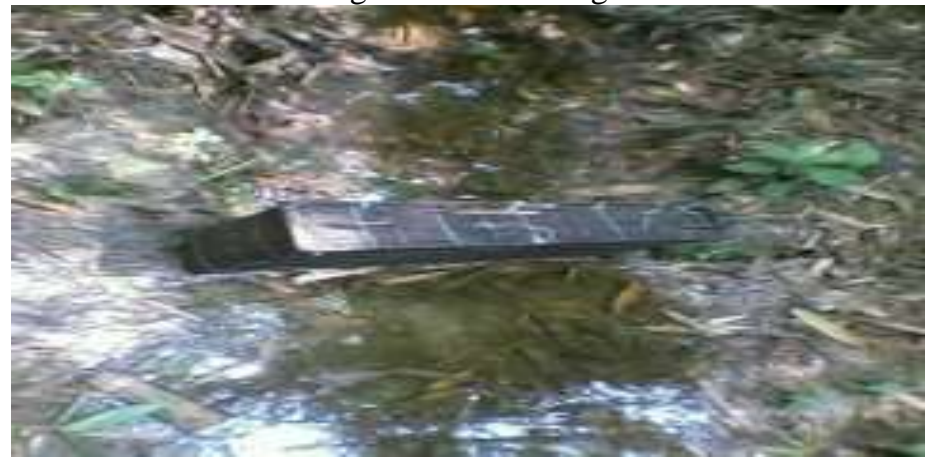

Fig. 5: Darki

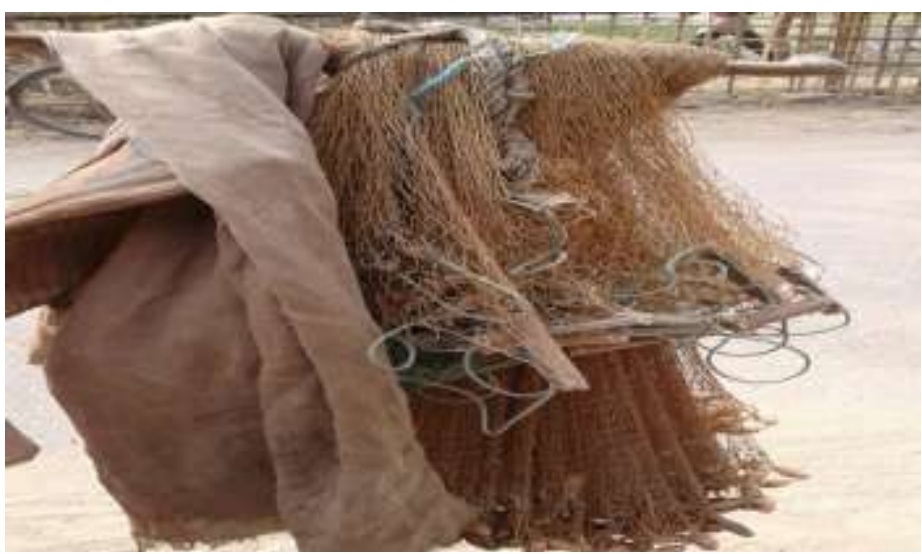

Fig. 6: Gore Langi 


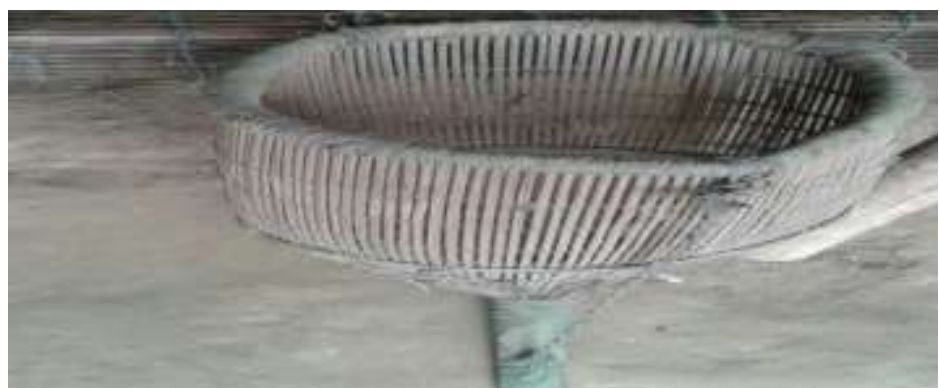

Fig.7: Loiha

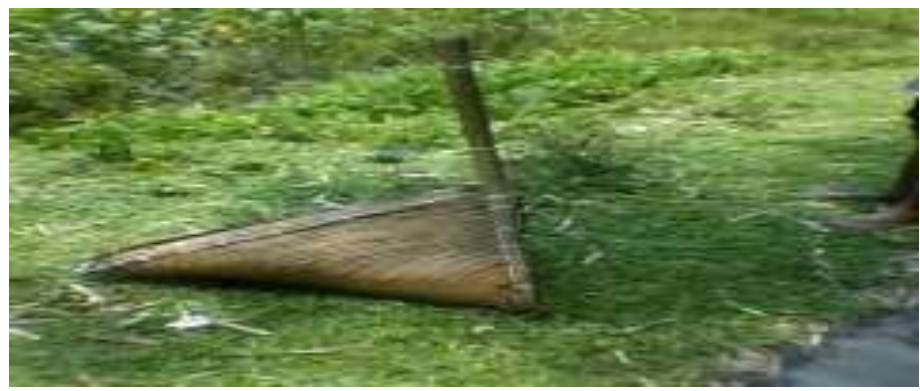

Fig. 8: Zakhe

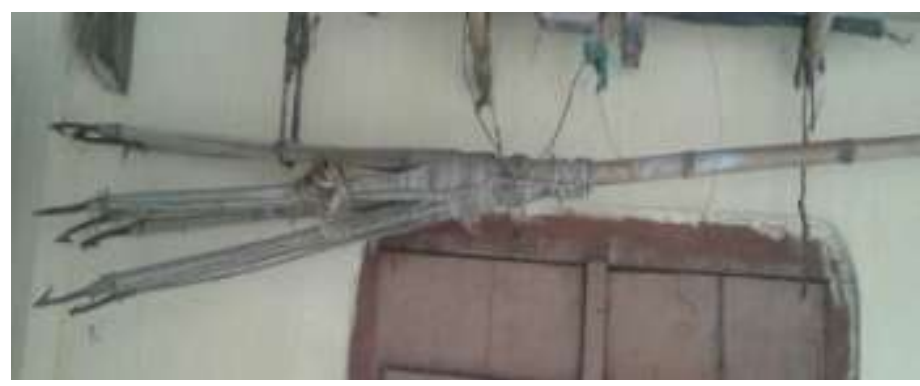

Fig. 9: Koinal

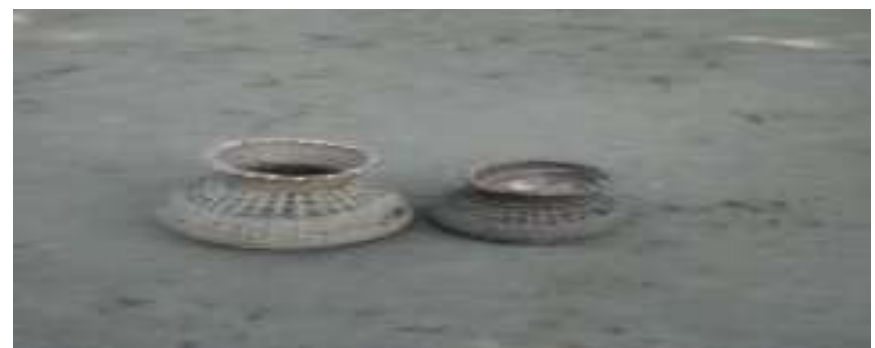

Fig. 10: Kok

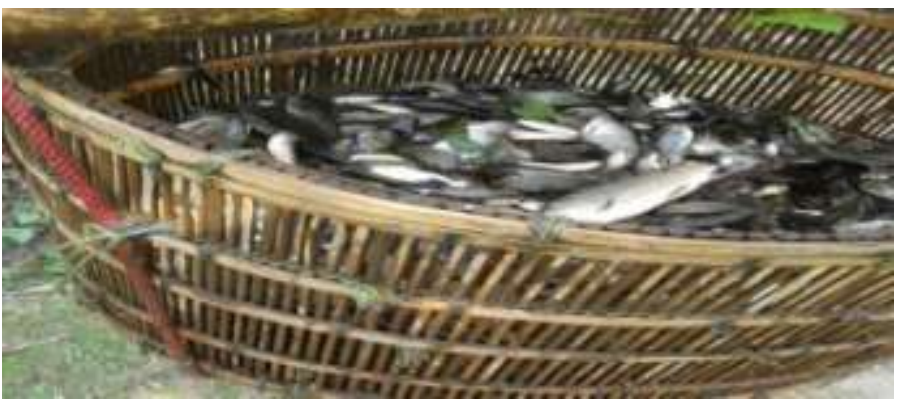

Fig. 11: Deli or Gas 


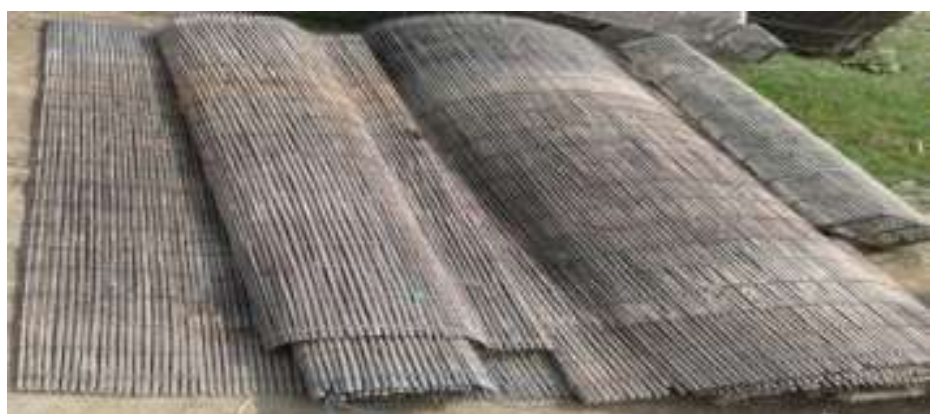

Fig. 12: Bana

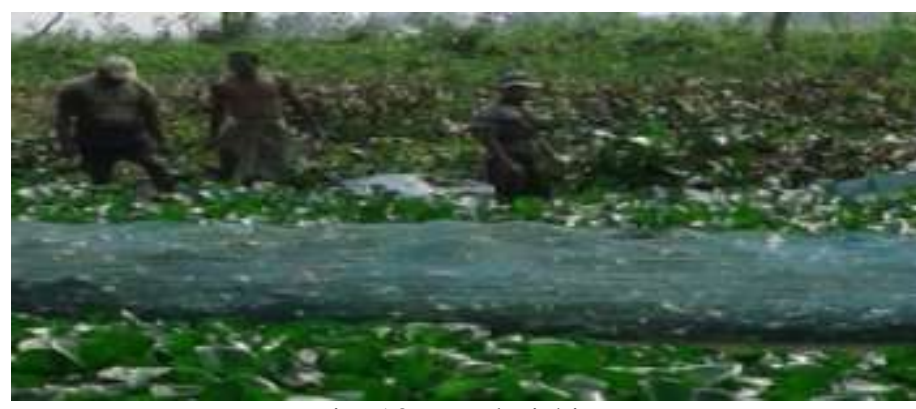

Fig. 13: Band Fishing

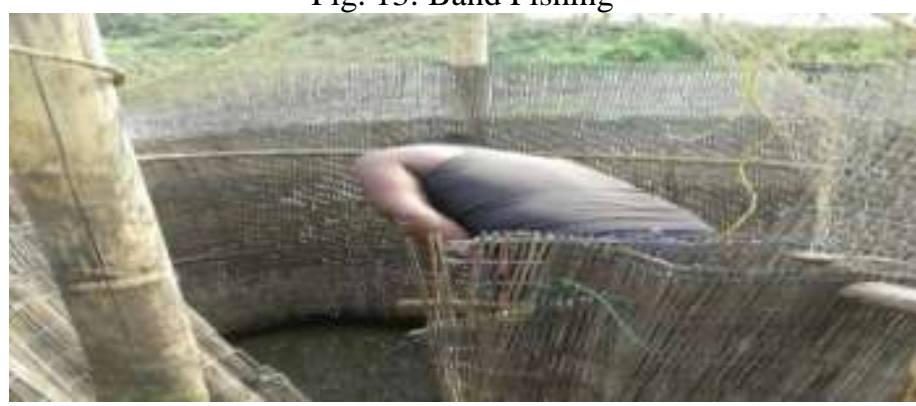

Fig. 14: Ghera Fishing

To make this net four pieces of bamboo sticks are used. These are fixed with a long piece of bamboo stick. It is used in the stream, pond and river during the rainy season. A piece of string is also used to check the net.

\section{FINDINGS}

The findings of the proposed study are as follows:

$>$ Kaibarttas are one of the prominent fishing communities among the sixteen scheduled caste communities having $28.04 \%$ in the district.

$>$ The traditional fishing methods and tools used by the Kaibarttas of this area have remained static in some places and have shown little improvement in other places.

$>$ The Kaibarttas of this area have been using the traditional fishing methods and tools in their day to day life fishing.

$>$ The kaibarttas of this area use several types of fishing nets, fishing tools made of bamboos and canes and fishing weapons made of iron.

$>$ 'Pouta Mara' is rarely adopted for fishing now and 'Safa Mara' is still used by the Kaibartta fisher folk.

\section{CONCLUSION}

No doubt the Kaibarttas are one of the prominent fishing communities in Assam. But at present this traditionally practised fishing occupation has been losing its importance among them. The fish species have been decreasing day by day due to the decline of the several water bodies. So if proper measures are taken by the state government, this community can really empower themselves economically and socially. Fishing could be taken as commercially in near future by the people of this community of this area 


\section{REFERENCES}

[1] D. K. Bezbaruah, Brahmaputra Upatyakar Kaibartta Jatir Ruparekha, (Guwahati, 1997) 6-14

[2] http://en.wikipedia.org/wiki/Mahishya

[3] S. Mitra, Sarala Bangla Abhidhan, (6 ${ }^{\text {th }}$ edition) 295

[4] R. N. Sarma, Principles of Sociology, (Asia Publishing House, New Delhi, 1971) 50

[5] D. K. Bezbaruah, Brahmaputra Upatyakar Kaibartta Jatir Ruprekha, (Guwahati, 1997) 22

[6] Census of India Assam, Scheduled Caste and Scheduled Tribe, (1961) 336

[7] D. Narayan, et al, Asamiya Sanskritr Kanika, (Chandra Prakash, Panbazar, Guwahati-1) p. 24

[8] Y. S. Yadav, et al, Limnology and Productivity of Dighali Beel, Assam, (India trop. Ecol., 1987)

[9] B. K. Baruah, A Cultural History of Assam, (Guwahati, 1986)

[10] S.K. Chatterji, Kirata-Jana-Kriti, (Calcutta, 1974)

[11] L. Gogoi, Asomor Sanskriti, (Dibrugarh, 2009)

[12] M. R. Darshan, Folklore and folklorists: An Introduction, (1968)

[13] N. C. Sarma, Asomiaya Lok Sanskritir Abhas, (Guwahati, 2007)

[14] E. B. Tylor, Primitive Culture, (New York, 1874) 